\title{
Practical Use and Regenerative Role of Theories of Intercultural Pedagogy in Educating Disadvantaged (Minority) Students
}

\author{
Zoltán Simon \\ University of Miskolc, HUNGARY \\ Institute of Anthropological and Philosophical Studies
}

Received 18 June 2019 • Revised 27 August 2019 • Accepted 6 September 2019

\begin{abstract}
In this essay the possibilities for the practical application of Hungarian intercultural pedagogy are analyzed showing the reflective practice of cultural anthropology. In Hungary a unitedly accepted model of intercultural pedagogy does not exist and the process of its creation is also full of obstacles. Forming the right method means interfering the everyday life of school communities and the knowledge of the usual working process in the school educational system is also assumed, A long, problem-driven research using anthropological methods (participant observation, action research) is needed to examine the group dynamics of children with a different cultural background within the same school by intercultural pedagogy. The culture of the school itself is also one of the venues of social environment but to be able to get to know the students' point of view concerning their own school we will need several qualitative social examinations in the near future. Teachers working in the Hungarian educational system have not been able to prepare for educating disadvantaged students and ethnically/culturally heterogeneous classes yet. My essay is trying to refer to the educational transformations which have been totally altered because social tensions are immediately represented in schools. The school community reflects our social system. Without realizing it schools are not able to form a certain relationship with children. They have to see children not only as members of a particular family unit, but children also have to be seen in their global social relationship which is not neutral concerning the explanations of social and educational events.
\end{abstract}

Keywords: intercultural pedagogy, cultural anthropology, anthropological pedagogy.

\section{Introduction}

In Hungary, school integration has not been able to decrease social, sociocultural and ethnic differences in public education. The continual and consecutive desegregation efforts have only been realized in a formal way. Educational policies and practices of institutionalized integration have not been able to get past the basic level of theoretical, scientific discourse. The theoretical lack of proof regarding the issue entails that there has not developed a critical reflection, an objective educational policy approach that is both adaptive and problem-oriented. This does not mean that in the period after the regime change there were no preferential political solutions intent to eliminate social inequalities - the hiatus on the issue is the consequence of the incomplete social-educational-political discourse that still cannot answer the question of how to

(C) Authors. Terms and conditions of Creative Commons Attribution 4.0 International (CC BY 4.0) apply. Correspondence: Zoltán Simon, University of Miskolc, Institute of Anthropological and Philosophical Studies, HUNGARY. E-mail: nyarad@gmail.com. 
do away with social and ethnic differences in the school. To put it more precisely: what tools are needed to ensure equal treatment in school integration in such a way that it may point beyond the structural confines of equal opportunities and the physical methods of access to schooling? ${ }^{1}$ Scientific pedagogical discourse constantly reflect on this question. In response to the outcomes of relevant scientific research, pedagogical experts claim that school integration efforts have mostly halted or been left unfinished, since in the long run they did not result in a change of perspective for teachers, for education per se; that is, regarding its relations with disadvantaged (or minority) children, the social role and responsibility of the school has hardly changed.

The way the present paper addresses the issue of disadvantaged children living in deep poverty, socio-culturally different and culturally other, signals a wish to echo the scientific discourse between cultural anthropology and various social science theories; it is also an operative description that may regenerate (or transform) pedagogical theory and practice. The concept of intercultural pedagogy and the use thereof in pedagogical discourse is not adequately clarified. For this reason, the paper intends to be a gap-filler: to clarify the concept of intercultural pedagogy and attempt to reconsider it with the help of a holistic approach and interdisciplinarity of cultural anthropology, striving to avoid being purely descriptive and speculative ${ }^{2}$. Due limited space and research being in its initial stage, the paper does not - cannot - undertake the historical description of anthropological pedagogy; nor does it include the empirical verification of theoretical hypotheses. A substantial part of international theoretical literature asserts that the difficulty of applying intercultural pedagogy lies in the compatibility of theory and practice, and this may be one of the reasons why, in the long run, it has not been able to become a unified, general educational concept (in Western Europe either). On the other hand, accounts summarizing the pedagogical goal of intercultural education exhaustively reveal that the major goal of intercultural education today - likely to be responsible for its success - is to undertake the task of cultural transmission in an innovative way, both in terms of its dimension and versatility (Reich, 2008: 68).

\section{Intercultural pedagogy adapted to practice}

Intercultural pedagogy has been greatly affected by the cultural anthropology approach. This paper deals with pedagogical anthropology as a call for discussion, a theoretical

\footnotetext{
${ }^{1}$ For a more detailed discussion of the issue see Forray and Varga (2014).

${ }^{2}$ For the purposes of this paper, it is important to briefly deal with the scientific concept of cultural anthropology, as a complementary explanation to the essence of the holistic approach - to reconsider how it correlates with didactics; how, in a strict sense, it intends to affect the specific areas of pedagogy, especially intercultural pedagogy. This means that the need for interdisciplinarity derives naturally from the history of anthropology. As András Bán, Gábor Biczó and József Kotics (2005) contend, it is well known that the applied knowledge of social science resulted in the emergence of an independent, highly respected profession in Western societies. The social and cultural processes of transformation in Hungary today demand the involvement of professionals with an interdisciplinary, directly applicable practical knowledge of social science who are capable of taking a stand in the various areas of social life in a way that is competent and that facilitates the opinions of decision makers, and who can react to conflicts and social crises in a creative way. Intrinsic and direct information is a vital element of accurate knowledge needed for practical decisions. This approach has an accentuated role in the investigation of the sociocultural phenomena of our times, since the traditional framework of lifestyles and values has been dismantled. The complex plurality of lifestyles and life strategies, emerging as a result of this process, requires a comprehensive approach. Due to its holistic and comparative approach, its cultural relativism and position as a participant-observer, the anthropological perspective can transmit knowledge about changes in our society (such as joining the European Union, globalisation, processes of migration and assimilation, the emergence of the information society, and expectations of the social equalisation of chances), which may contribute to successfully dealing with issues requiring social action (cf. Bán, Biczó \& Kotics, 2005: 35-36).
} 
reflection which seeks to find pedagogical arguments and answers to the interrelationships of culture and education, as well as the causes of social inequalities. Inasmuch as we accept that intercultural pedagogy is, ultimately, a cultural transmission, then is timely to raise awareness of the fact that cultural diversity is not a problem - it is present; its processes have a deep impact and necessitate new discourse and agreement on social coexistence. The proper recognition of social reality demands such capacities from students that need to be taught, developed, and also, if necessary, supplemented or emended. Hans H. Reich's analysis of intercultural education (2008: 66-69) excellently outlines the chances of intercultural pedagogy in the future. Proceeding from criticism on intercultural pedagogy, Reich takes account of the difficulties of the approach and can thus revindicate the role of intercultural education (which flourished in Western Europe for a long time) as an 'emergency warden' The regenerative role of intercultural pedagogy in educating disadvantaged (minority) students can only be successful if we interpret education as a phenomenon in social interaction (cf. Alcalde, 2008: 18). This definition by José Eugenio Abajo Alcalde derives from the basic assumption that education is ultimately a process and an interpersonal activity. Conducting participant observation, Alcalde investigated the schooling of Roma (gitani) children in Aranda de Duero (Castile, Spain) from this perspective. The description of his subject of research is consistent with the issue raised by this paper: he emphasizes the importance of taking into account the global social context and model (domestic groups, school types, relations between schools and various social groups, the social stage of everyday life, interactions between persons and groups, etc.) when conducting research on the schooling of Roma children. In short, Alcalde interprets the global social context as a structure that has a major impact on all other phenomena, and he claims this to be generally valid (18).

Extrapolating this train of thought to the educational situation of disadvantaged (Roma) students (with regard to the social/educational interactions of Roma people in Hungary), it may be stated that the practical goal of theories of intercultural pedagogy is to undertake the additional social and pedagogical work of interpreting social and school integration not only as a minority problem, but as a social issue strongly affecting the majority as well (!), the basis of common social life. To make this a reality, a social and cultural development or even transformation (interwoven with strong political will) must take place. In several parts of Western Europe, we may witness a process in which accumulating social disadvantages are decreased by joint social and political will. These processes are characteristically supplemented by a disciplinary endeavor, in which social scientists (in most cases social anthropologists) ${ }^{3}$, offer a relevant empirical action research that can have a direct impact on social processes, an educational policy alternative that clearly reveals the needs and shortcomings of the social-educational process

3 Foyer Regional Integration Centre in Brussels, led by social anthropologist Johan Leman. For decades the institution has offered alternative education and training for various ethnic and cultural minority groups and members, and worked to ensure their social and school integration. Through diverse training programs, Foyer facilitates the school reintegration of young immigrants (men and women alike) via career guidance support. Sanctioned by the government of Brussels since 1985, the Foyer Centre provides vocational training for young immigrants (in the fields of wood working, construction and electrical energy). In many cases, the children of immigrant families are unfairly expelled from school or they feel that they cannot continue their studies, so Foyer has professional study programs at its Vocational Training Centre, operating with a group of advisors, and with legal assistance, thereby facilitating school integration and success. In the near future, Hungary will also increasingly experience a flow of immigrants into the country. In the meantime a strongly predictable increase in the Roma population, the shift of social levels and factors towards more extreme directions, and the growing number of disadvantaged Roma children in vocational training will more or less result in the same social-educational situation that we are witnessing in Western Europe at present. Foyer Regional Integration Centre displays a number of similarities with the Világsátor Project of Roma Cultural Centre in Miskolc. This project was abruptly stopped, even though it could have ensured a kind of professional workshop that would have enabled the social forum of pedagogical anthropology and intercultural education to evolve. For Foyer's professional study program see www.foyer.be. 
through the research methods of pedagogical anthropology (comparativism) (cf. Pampanini, 2010).

Each culture is mixed, each is changing and adapting to its environmental conditions. If we regard the plurality of cultures as existing, we are bound to accept that the cultural identity of a certain person or group is not incompatible with the identity of another culture. People are entitled to get to know another culture, that is, no-one can question an open human attitude, empathy that denotes a curiosity concerning anything culturally other - in our case, a respect for cultural differences (Alcalde, 2008: 290). The methodology of recognizing cultural differences has to be taught to students, as suppressing the difference between school culture and the culture of one's home may cause significant tension in the life of a school. Cultural encounters are taking place in the school as an institution and as a place of institutionalized (secondary) socialization (unless the school does not select or segregate) more and more frequently in Hungary (to a greater degree in some regions) as well.

We can only get rid of our ethnocentric attitude through conscious learning, in a selfreflective manner, with self-criticism. We generally tend to see and interpret our surroundings through the lens of our own culture. In the world of the school this means that, due to the difference between the school and the culture of the students' family/home, teachers do not recognize the students' abilities and intentions. Such a bifocal pedagogical lens - metaphorically speaking - can easily lead to a situation in which the teachers' educational or disciplinary method is incomprehensible and impossible for such students (Delpit, 2007: 29).

In his analysis Reich asserts that the notion of intercultural education wishes to establish mutual respect for different cultures based fundamentally on moral arguments, and for this very reason it urges the reform of the curriculum, valid on various levels of education. The goal or requirement that it sets is the need for the cultural canon - transmitted by education - to reflect not only majority high culture but minority and subcultures as well, and for the school to allow, what is more, encourage the self-representation of these minorities (Reich, 2008: 69).

The communicational strategies of Hungarian public education should strive to build a bridge between official culture and the other cultures. Intercultural education should enter scientific thinking, since its greatest merit is making us aware of how important and relevant the issue is. The rules for social co-existence In Hungary should be urgently reconsidered. In essence, intercultural education is the alarm-bell that calls us to new ways of thinking about, and civilized opportunities of acting for, cultural and social diversity and differences through public education. In this dialogue of power the political responsibility of the program exists and remains (Reich, 2008: 69).

Recent theoretical literature - and primarily international and Hungarian pedagogy specialists with multidisciplinary expertise - sees a greater methodological opportunity in intercultural education today, and believes that multicultural education needs to be complemented by emphasizing the teachers' role as transmitters of culture. More specifically, in pursuance of intercultural competence, teachers have to reconsider their pedagogical activity (cf. K. Nagy) and take in part in the development of children's cultural identity, in the formation of individual cultural identity4. We are hoping for reform, for the transformation of our pedagogical culture with the help an intercultural competence toolkit which - beyond and besides a top-down integration policy - enables students and teachers to mutually accept each other's social and cultural reality and to develop their own methods of integration along the lines of student diversity, relying on their own school experiences and aided by teacher-student communication.

4 For a more elaborate account of this issue see Szerepi (2005: 129). 
3. Towards the quality reform of teacher training - the present and future perspectives of intercultural pedagogy

The lack of intercultural pedagogy in multicultural societies, such as Hungary, may cause a pathological condition - claims Cecília Tusa (2009), referring to József Zsolnai. Following on Tusa's reasoning, we may assert that this pathological condition in the teaching-educational process means a diversion from constructive work, heading in a negative direction. From this aspect of the interpretation of intercultural pedagogy, we may say that such a pathology does not take into account the globalization of $21^{\text {st }}$-century societies and the resulting recent pedagogical challenges of a united Europe (Tusa, 2009). Defining a system of objectives and tasks for intercultural education, the International Conference on Education (ICE), organized by UNESCO in 1992, was the first to react to the new pedagogical challenges uniformly affecting Europe (Majzik, 1995: 79). The conference papers all dealt with the issue of intercultural education and defined teachers' tasks in this context. The conference material was determined by the working papers prepared in advance by IIEP UNESCO (International Institute for Education Planning) in Paris, and concentrated on intercultural and multicultural concepts with the aim of understanding the nature of intercultural interaction and of outlining the possibilities of co-existence in multicultural societies. The terms education and culture were brought closer together, and the essays shed light on the pedagogical fact that education contributes to cultural development, but the main question was how this can be done (Majzik, 1995: 80). The editor of the conference proceedings, Dubbeldam, analyzed more than a hundred definitions of culture that were disclosed to UNESCO member states in the conference's preparatory material. According to the definitions, the conference agreed that in its widest sense, culture may now be said to be the whole complex of distinctive spiritual, material, intellectual and emotional features that characterize a society or social group. It includes not only the arts and letters, but also modes of life, the fundamental rights of the human being, value systems, traditions and beliefs that it is culture that gives man the ability to reflect upon himself. It is culture that makes us specifically human, rational beings, endowed with a critical judgment and a sense of moral commitment. It is through culture that we discern values and make choices. It is through culture that man expresses himself, becomes aware of himself, and recognizes his incompleteness, questions his own achievements, seeks untiringly for new meanings and creates works through which he transcends his limitations (UNESCO, 1982).

On the basis of the quotation perhaps it is discernible that $21^{\text {st-century pedagogical }}$ challenges - in Hungary as much as in unified and globalizing Europe - induce an interdisciplinary attitude and theoretical viewpoints such as pluridisciplinarity and transdisciplinarity 5 . Accordingly, the relationship between various disciplines and subdisciplines should be mutual and systematic, but in some cases it might as well be contradictory. More specifically, the link between social sciences and the humanities should be recognized as soon as possible, since the most crucial and acute problems of our "global village"6 (first and foremost poverty and ignorance) cannot even be approached without such attitudes.

5 These concepts are interpreted as follows: interdisciplinarity - a cooperation between various disciplines regarding complex problems which can only be dealt with and through the combination of different approaches; pluridisciplinarity - the juxtaposition of disciplines, assuming a more or less strong mutual relationship among them; transdisciplinarity - refers to a general axiomatic system or a theory (assuming a conceptual, or leastwise harmonious unity) which colligates a whole group of disciplines (such as totality, mutual relationship, change or contradiction) (Majzik, 1995: 88).

${ }^{6}$ Ernő Kunt (1994) deploys McLuhan's concept of the "global village" in interpreting globalisation from the perspective of cultural anthropology. In Kunt's view, our age is increasingly characterised by an information network with multiple links between the continents, which reacts as sensitively and effectively to events happening in the most varied and geographically remote areas, and creates international and global correlations as fast as the human nervous system responds to any stimulus in or affecting the body immediately and with comprehensive evaluation. As Kunt notes, the developers, operators, maintainers, 
The presenters of the ICE Conference covered the historical aspects of both formal and informal education and defined their agents of cultural transmission. Based on these theses, the essence of promoting intercultural education was concentrated in the pedagogical thought that interaction needs to be established between students and different cultural groups in multiethnic societies. Intercultural education has to point beyond the mere transmittance of knowledge, and where there is no opportunity to do so, different cultures and lifestyles need to be brought closer to students with the help of project-based methods (Majzik, 1995: 81).

This paper perceives the present and future perspective of intercultural pedagogy to lie in the task of shifting the right of cultural transmission to intercultural pedagogy (education). Through the mutual interests of multicultural education and intercultural pedagogy, such a cultural transmission joins two disciplines: pedagogy and cultural studies (cf. Tusa, 2009).

In the case of linking the mutual interests of multicultural education and intercultural pedagogy, this paper does not touch upon the semantic deconstruction of the historical traditions and cultural definitions involved in the interpretation of these concepts. The use of the concepts of multicultural and intercultural education varies by country and within Hungarian scientific discourse as well, resulting in different interpretations. In Hungary it was Judit Torgyik who wrote several detailed and professional studies and books about multicultural education - this paper adapts all the factors of the process of multicultural education 7 as described by Torgyik. In the context of our topic, the most relevant issue is to grasp the essential terminological differences between multicultural education and intercultural pedagogy. From this perspective there may still remain some uncertainties, but if we provide a combined and comparative description of multicultural and intercultural education, then-as recent international and Hungarian theoretical literature reveal- the discrepancies/differences between the components become visible in the competence areas. In reference to a methodological work published by an Irish school, Sándor Szerepi differentiates between multicultural and intercultural societies: the former means the coexistence of different cultures without any interaction, while the latter denotes an intensive relationship between cultures living side by side and the mutual process of recognition, experience and cultural enrichment as a result of this interaction (2005: 129). Cecília Tusa (2009) refers to and cites Mrs. László Majzik, Ildikó Mihály, István Aranyosi, Zoltán Kovács and Erzsébet Cs. Czachesz in revealing how the use of the concepts 'intercultural' and 'multicultural' is inconsistent and divergent in Hungarian theoretical literature.

In the context of this paper, intercultural pedagogy is a kind of microscope that relates to the issue of social and cultural equality through the lens of the world of the school. It explains what cultural lens is needed for teachers to compensate for practices of social discrimination, how the deficit-defying viewpoint of unnoticed and unrecognized identities and cultural affiliations may be put into practice in the school and how it can be planted in teachers' minds. Ethnic interactions and the resulting differences surely gather in the school, owing to newer and newer

participants and recipients of these international information networks have formed a global society with increasingly salient peculiarities - a global society which creates and rapidly develops a worldwide global culture besides, beyond and even in the face of traditional national cultures. In a certain respect and to a certain extent, the world has shrunk and appears to be as transparent as a village is to a peasant living there. In Kunt's words, social science education at the millennium should provide sufficient preparation and sensitivity for university graduates to be capable of recognising and understanding the society and culture of what McLuhan termed a "global village" - or at least to be aware of its existence, while working in their own specific fields.

7 For experts and (prospective) teachers Judit Torgyik's book on multicultural education (2005) is a mustread. It is a "gap-filler" study which provides an exact investigation of the historical aspects and methodological issues of multicultural education as a pedagogical subdiscipline, and focuses on the Roma

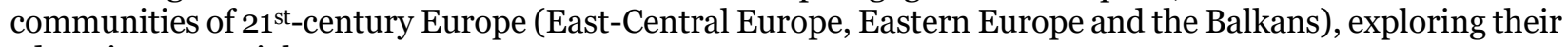
education potential. 
generations, generating conflict and disadvantage. The primary goal of the school is, however, to provide a locus for secondary socialization - regardless of cultural and ethnic origin - which facilitates social integration (as far as possible in an equal manner).

Intercultural pedagogy can convey this openness, a mutual and equivalent strategy for socialization, and it holds the possibility of successfully adopting the approach of equal treatment in the school by using the most effective method: calling teachers' attention to the need for learning to reflect on their own behavior, to direct their reflection beyond teachers' and students' behavior to the social processes of knowledge building, to base their cultural reflections on the fact that school children mirror society, the locus of primary socialization (including the family as a micro social institution). Racist, xenophobic attitudes shall not be allowed/ tolerated in the school instead, new techniques, which help manage cultural and ethnic conflicts deriving from social discourse and practice outside of the school, have to be designed and implemented through the project method and co-operation (cf. Feischmidt \& Vidra, 2011: 57-60).

Intercultural pedagogy provides us the possibility of increased attention to (the quality of) ethnic interactions, primarily adapting the research methods and theoretical framework of cultural anthropology, and, within it also of social anthropology. The scope of the present paper shall be expanded in the near future by the hypothesis that the discursive practice of intercultural pedagogy needs to bear in mind the essential difference between etic and emic positions as established in cultural anthropology research traditions. This means that the practice of intercultural pedagogy can only be adequate - that, is emic - if it teaches the representatives of different cultures how to identify with/relate to and mutually immerse in each other's culture. Along the lines of intercultural thinking, we may create a kind of anthropological pedagogy that teaches us not to equate the respective concepts of culture and ethnic identity, not to view culture as a synonym for identity politics, but to define it as the essence of an ethnic community/group (cf. Turner, 1997: 109). This way we may avoid drawing a socio-cultural dividing line between majority and minority - if we do draw this line, we find ourselves in an etic position, observing the cultural other from outside, through our own cultural lens.

4. The perspectives of pedagogical anthropology and intercultural pedagogy in educating disadvantaged (Roma) students

Essentially, multicultural education encourages us to be patient with minorities within a majority society; the solutions it proposes are primarily concerned with the educational and teaching tasks of the school. Intercultural pedagogy does not refuse to deal with conflicts deriving from social co-habitation at the level of the school (i.e. institutionally). From this point of view it not only proposes that cultural diversity and difference are generated in relation to ethnicity, but also adds that they are historically variable and dependent on social goals. One of the most vital thesis of intercultural pedagogy is that cultural difference, as well as personal and group identity, are not merely cultural attributes but objective social habits correlating with social goals (cf. Lesznyák \& Czachesz, 1998: 7-9).

Let us return to the primary issue of the perspectives of intercultural pedagogy in educating disadvantaged (Roma) students here. In his study on innovative educational efforts, Péter Bogdán (2012) investigates the education of disadvantaged Roma students in Hungary and reveals the basic problems concerning their education. First of all, he notes that the currently valid methodology, requirements and teaching methods used by the Hungarian education system demand a minimum socialization and financial level from Roma children that most of them cannot meet, and thus they fail at school, become private students - that is, they fall through the safety net of the educational system. Furthermore, Bogdán asserts that since the regime change in 1989, only those Roma children could become successful who, for various reasons, could reach the above mentioned socialisation and financial level. Bogdán also mentions the success of applying 
alternative pedagogical methods as opposed to traditional education. He believes alternative methods to be more efficient since they are personality-centered and properly deal with social problems ${ }^{8}$.

Bogdán's findings signal a recognition that practice-oriented intercultural pedagogy can only be truly successful if it equips itself with alternative pedagogical trends, and it is most efficient where, compared to the threshold of traditional schools, there is no minimum socialization and financial level. Bogdán finds that alternative pedagogies decrease social disadvantages, not only in the case of Roma children, but also in that of poor, non-Roma students, as alternative pedagogy and intercultural pedagogy are not ethnic remedies, but possible tools.

Henceforward, drawing on Sándor Szerepi's thesis, the paper shares the view that Western European and American models of intercultural and multicultural educational cannot be uniformly adapted, as the situation of Roma people in Central and Eastern Europe differs fundamentally from that of both Western European immigrants and historical minorities. The most vital elements here are the Roma population's deformed/fragmented social structure and their poor living conditions, which complement, or are rather substantiated by, differing socialisation processes rendering integration into majority society significantly difficult (Szerepi, 2005: 130).

We may borrow the (basic) hypotheses of several such research studies ${ }^{9}$ available at the moment, but each is unique, with a specific space and time segment. Therefore the main characteristic of relevant research using quantitative and qualitative methods is that each case refers to a wider environment, and the hypotheses may be adapted to a more comprehensive social context as well ${ }^{10}$.

\section{Instead of an afterword}

The concept of intercultural education is - theoretically - well-elaborated in international and Hungarian theoretical literature, but the dissonance between theory and practice is not eliminated in a descriptive way. I do not regard the practical usage and description of the theories of intercultural pedagogy (as conceived in this paper) as closed - in order to avoid obscurity, further investigation of the issue requires the application of empirical research methods.

For the purposes of the TÁMOP 4.1.2-B.2-13/1-2013-2015 project entitled "Cooperation for the Regeneration of Teacher Training in Northern Hungary," it is highly essential that the concept of intercultural pedagogy become more well-known in Hungarian pedagogical

\footnotetext{
${ }^{8}$ As a practicing secondary school teacher I share Péter Bogdán's view. As I see it, alternative methods and methods of reform pedagogy are more effective in educating disadvantaged students (as is the case with any other school, class or age group). It must be noted, though, that in my practical experience sometimes alternative methods can only slightly reduce latent prejudice in the classroom, and can hardly do away with it entirely.

9 We must mention the EDUMIGROM research project in particular (for more details see www.edumigrom.eu), which, in the case of Hungary, examined schools' attitudes to minority integration, de- and re-segregation. For a more elaborate account of the project see Feischmidt and Vidra (2011: 57-95). ${ }^{10}$ Enikő Vincze and Hajnalka Harbula of the Hungarian EDUMIGROM research team conducted research on the Roma in Romania and Transylvania.Their findings demonstrate the comparativity of Roma people's social exclusion. The political and societal will to improve the educational situation of Roma communities in Romania corresponds to political efforts in Hungary. In accordance with the objectives of the "Cooperation for the Regeneration of Teacher Training in Northern Hungary" TÁMOP project and as a result of their similar concepts of research, a working relationship has been built with some members of the Romanian EDUMIGROM research team. See Vincze and Harbula (2011).
} 
thinking ${ }^{11}$. Since there is no classic model of intercultural pedagogy, the path towards producing such a model in Hungary appears to be fairly long. Creating the method involves interfering with the life of the communities in question, and presupposes an insight into the daily life of the institutional system of school. Hungarian Roma communities are quite heterogeneous in terms of their cultural and socio-economic patterns. We need problem-oriented research conducted with long-term anthropological methods (particularly participant observation) so that intercultural pedagogy can examine the group dynamics of school children having different cultural origins. This requires mapping the social networks of students groups and measuring the neighborhood interactions and socio-cultural relations of members and children of the observed minority community, and then the collocation of this data with the school performance of the children of that group.

It is the outcomes of the preventive research studies outlined above that should provide the foundation for the practice-oriented pedagogical work based on which the competence areas of intercultural pedagogy could be defined for each target group ${ }^{12}$. The presence of disadvantaged Roma students in the school network in Northern Hungary is divergent. At international and national levels, intercultural education is most developed and practical in crèche and primary school education ${ }^{13}$, while in secondary schools there is hardly any space for intercultural education, and the teachers' relevant competences at this level show the greatest deficiencies. Intercultural pedagogy should be present at all levels of education and training. Teachers in the public education system could not yet prepare - even in a methodological sense to receive disadvantaged Roma students and ethnically/culturally heterogeneous classes. In this respect, most secondary grammar schools show selectivity; practice-oriented intercultural education in these institutions can only gain ground by external (nationally or locally initiated) educational governance (since the number of disadvantaged Roma students is the lowest in these schools). Certain school types and the socio-cultural backgrounds of their students may divert the direction of the gains made by intercultural pedagogy in secondary schools.

The Roma/Gypsies Research Centre of René Descartes University completed a multivolume study in 1984-85 and made recommendations for educating European Roma. Besides listing a great number of educational issues, the study emphasized that the measures taken in the

\footnotetext{
${ }^{11}$ Alcalde's book on Roma children in the school - the most important experimental study of pedagogical anthropology - describes how he consulted with the Association of Teachers of Roma people (wellfunctioning in Spanish public education) to test his hypotheses (2008: 15). Setting up a similar association in Hungary through official consultations is highly essential.

${ }^{12}$ I shall summarize the fundamental guiding principles of intercultural education based on the professional program of the International Conference on Education. According to ICE, teachers should be more sensitive to students' needs, interaction should take place in the process of education in accordance with each student's culture; teachers should be able to link what is prescribed and what is intended to be taught, and should tailor these to the requirements of students with different cultural backgrounds; teachers play a primary role in transmitting and developing culture, since intercultural pedagogy equates education and cultural transmission; teachers should be attentive to their own cultural roles and it is highly important that they transmit their own attitudes, opinions and values when needed, and that they express objective criticism on current social and political issues; regardless of how restricted teachers are in institutional terms, they should strive to and actually use informal education, following the required ethical rules when developing personal relationships with students; it is crucial that in the process of education teachers place cooperative learning methods in the foreground, urge the cultural development of local communities and encourage students to do the same, as well as facilitate the educational potentials of local collectives; intercultural pedagogy states that the most essential space for social relationships is the school, including the level of a classroom and groups of learners in a class as well, and that teachers should be able to recognize and handle all of this (Majzik, 1995: 88).

${ }^{13}$ See Judit Torgyik's (2008) book on multicultural practices, among a long list of similar methodological initiatives and volumes.
} 
name of establishing intercultural education open the way for a pedagogical practice that pays attention to each and every culture in the school and builds on the abilities and knowledge of each and every student. These changes may facilitate the school in adjusting to Roma children's needs (Liégeois, 2002: 16).

This paper has investigated a well-known yet also expanded educational program, and, more specifically, endeavored to (re-)integrate its theoretical background. We hope our analysis may give a more acceptable answer to the new educational transformations in Hungary. The school as a society mirrors our social structure; consequently, social tensions may also rise in the school and result in conflict and misunderstanding. Certainly intercultural pedagogy cannot evolve where intercultural politics does not gain ground (Liégeois, 2002: 16). In the absence of such a gain, the schools cannot set as an objective a kind of relationship with the students which requires them to reflect on the fact that a child is not only the member of a family but also a representative of a culture - children need to be recognized and seen in a global socio-political relationship which is not neutral from the aspect of explanations to social and educational phenomena. This statement does not wish to support the theory of social determinism, but aims at avoiding segregative contexts. This is the only way we can point out the direction we have to take to solve the problem. To overcome the schooling problem of disadvantaged children (and their families), beside social assistance programs, intercultural relationships based on equality and disadvantage-compensation are also needed (Alcalde, 2008: 287-97).

\section{Acknowledgements}

This research did not receive any specific grant from funding agencies in the public commercial, or not-for-profit sectors.

The author declares no competing interests.

\section{References}

Alcalde, J. E. A. (2008). Cigány gyerekek az iskolában [Gypsy children at school]. Budapest: Nyitott Könyvmúhely.

Bán, A., Biczó, G, \& Kotics, J. (2005). Megjegyzések a tudásterület múltjáról a jelen perspektívájából és a jövő érdekében [Remarks about the past of the area of knowledge from the perspective of the present in favor of the future]. Új Holnap Irodalom, kultúra, múvészet, társadalom, 4, 31-37.

Bogdán, P. (2012). Innovatív törekvések a roma oktatásban Magyarországon [Innovative efforts in educating gypsies in Hungary]. In: Bodonyi \& J. Györgyné Koncz (Eds.), Modern alternatív iskolák (pp. 93-112). Budapest, ELTE Eötvös Kiadó.

Bölcsészettudományi Kar (2014). Retrieved 22 October 2014, from http://janus.ttk.pte.hu/tamop/tananyagok/inkluzio_a felsooktatasban/index.html.

Delpit, L. (2007). Mások gyermekei: Hivatalos kultúra és kisebbségi tanuló [Children of others: Official culture and minority student]. Budapest: Educatio.

Feischmidt, M. \& Vidra, Zs. (2011). Az oktatási integráció társadalmi lenyomatai [Social impressions of educational integration]. In: N. Bárdi \& Á. Tóth (Eds.), Asszimiláció, integráció, szegregáció: Párhuzamos értelmezések és modellek a kisebbségkutatásban (pp. 57-95). Budapest, Argumentum.

Forray R. K., \& Varga, A. (2014). Inkluzió a felsőoktatásban [Inclusion in higher education]. Pécsi Egyetem. 
K. Nagy, E. (2004). Társadalmi együttélés - interkulturális nevelés [Social cohabitation - Intercultural education]. Zempléni Múzsa 4.2. n. pag. Retrieved 12 November 2014, from http://www.zemplenimuzsa.hu/o4 2/kangy.htm.

Kunt, E. (2014). Az antropológia keresése: A komplex kultúrakutatás és az identitás között - Feljegyzések a kultúra kutatásáról és oktatásáról [Researching anthropology: Between the complex cultural research and the identity. Notes about researching and teaching culture]. Miskolci Egyetem Bölcsészettudományi Kar, Kulturális és Vizuális Antropológiai Intézet, n. d. Retrieved 15 November 2014, from http://inka.kvat.uni-miskolc.hu/antro/doku/fa02.htm.

Lesznyák, M., \& Erzsébet, Cs. Cz. (1998). Multikulturális oktatási koncepciók [Multicultural educational concepts]. In: Cs. Cz. Erzsébet (Ed.), Multikulturális nevelés: Szöveggyưjtemény tanító- és tanárszakos hallgatók számára (pp. 7-18). Szeged, Mozaik.

Liégeois, J.-P. (2002). Kisebbség és oktatás - cigányok az iskolában [Minority and education-gypsies at school] (Translate: Judit Oláh \& Ilona Szávai). Budapest: Pont.

Majzik, L. (1995). Cseppben a tenger: Fejlődés, kultúra és nevelés (egy UNESCO évkönyvből [A drop in the ocean: Development, culture and education (UNESCO Yearbook)]. Új Pedagógiai Szemle, 14(4), 79-93.

Pampanini, G. (2010). Interculturalism, society and education. Introduction. Retrieved 16 November 2014, from $\quad$ https://www.sensepublishers.com/media/521-interculturalism-society-andeducation.pdf.

Reich H., H. (2008). Interkulturális nevelés: helyzetelemzés [Intercultural education: periodic review] (Translation: Ivett Volenszki). In: J. Torgyik (Ed.), Multikulturális tartalmak a pedagógiában (pp. 55-72). Budapest, Educatio.

Szerepi, S (2005). Az interkulturális kompetencia, mint szociálpedagógiai eszköztudás [Intercultural competency as social pedagogical literacy]. In: Gortha - Rákó Erzsébet (Ed.), Társadalomtudományi Tanulmányok V. - Szociálpedagógiai Tanulmányok (pp. 128-133). Debrecen, Debreceni Egyetemi Kiadó.

Torgyik, J. (2005). Fejezetek a multikulturális nevelésből [Chapters from multicultural education]. Budapest: ELTE Eötvös József Könyvkiadó.

Torgyik, J. (2008). Minden nap ünnep: Multikulturális gyakorlatok itthon [Each day is a holiday: Multicultural exercises in the country]. Integrációs Pedagógiai Múhely Füzetek 2. Budapest: Educatio.

Turner, T. (1997). Az antropológia és a multikulturalizmus, avagy miért törődjön a multikulturalizmus az antropológiával? [Anthropology and multiculturalism or why is it important for multiculturalism to take anthropology into account?]. In: M. Feischmidt (Ed.), Multikulturalizmus (pp. 109-124). Budapest, Osiris.

Tusa, C. (2009). Multikulturális tevékenységre való felkészítés a tanárképzésben Magyarországon [Preparation for multicultural activities in teacher training in Hungary]. Pannon Egyetem, Retrieved 12 November 2014, from http://scipa.unipannon.hu/index.php?option=com content\&task=view\&id=66\&Itemid=35\#

UNESCO (1982). Mexico City Declaration on Cultural Policies: World Conference on Cultural Policies. Mexico City, 26 July-6 August 1982. United Nations Educational, Scientific and Cultural Organisation. UNESCO, n. d. Retrieved 30 May 2015, from https://unesdoc.unesco.org/ark:/48223/pfooo0052505.

Vincze, E. \& Harbula, H. (2011). Ştrategii identitare şi educaţie şcolară. Raport de cercetare despre accesul copiilor romi la şcoală (Edumigrom - România) [Identity strategies and school education, a compilation of the reports produced on Romania within the Edumigrom]. Cluj: Editura Fundaţiei pentru Studii Europene. 
Z. Simon - Practical Use and Regenerative Role of Theories of Intercultural Pedagogy...

C O A $\mathbf{s}$ 